\title{
Effect of Trifloxystrobin on Hatching, Survival, and Gene Expression of Endocrine Biomarkers in Early Life Stages of Medaka (Oryzias latipes)
}

\author{
Lifei Zhu, ${ }^{*}$ Huili Wang, ${ }^{*}$ Huijun Liu, Wei Li \\ Research Center for Eco-Environmental Sciences, Chinese Academy of Sciences, \\ P.O. Box 2871, Beijing 100085, China
}

Received 25 August 2013; revised 5 December 2013; accepted 12 December 2013

\begin{abstract}
Trifloxystrobin is a systemic broad-spectrum foliar strobilurin fungicides that enters the aquatic environment during agricultural application. It is highly toxic and poses a potential risk to aquatic organisms, whereas the effect on the development of early life stages of fish are unclear. In this study, hatchability, time to hatching, and larval mortality were measured. Additionally, the expression of biomarker genes, including those involved in sex hormone pathways (er, vtg, cyp17, and cyp 19a), thyroid hormone pathways (tro and dio2), and aryl hydrocarbon receptor pathways (ahr and cyp 1a), was determined after embryos of medaka (Oryzias latipes) were exposed to different levels of trifloxystrobin $(0,0.1,1,10$, and $100 \mu \mathrm{g} / \mathrm{L})$ for 28 days. The results showed that there were significant differences between controls and the $100 \mu \mathrm{g} / \mathrm{L}$ treatment group in both hatchability and time to hatching of fertilized eggs $(p<0.05)$. Larval mortality was significantly increased in the $0.1,1$, and $10 \mu \mathrm{g} / \mathrm{L}$ treatment groups $(p<0.05)$. These results indicate that embryonic and larval development may be affected by trifloxystrobin exposure. Moreover, the mRNA levels of the er gene were significantly upregulated at levels of trifloxystrobin above $1 \mu \mathrm{g} / \mathrm{L}$ treatment groups. Up-regulation of vtg, cyp 17, and cyp19a mRNA levels was observed in the larvae at the lower concentration treatment groups. The mRNA levels of cyp1a genes were significantly up-regulated at all of the treatment groups. These results suggest that trifloxystrobin is a potential endocrine disruptor through effects on the sex hormone pathway and xenobiotic metabolism. The changes in cyp 1a expression can be used as a highly sensitive biomarker to assess trifloxystrobin contamination in the early life stages of fish. ( ) 2013 Wiley Periodicals, Inc. Environ Toxicol 30: 648-655, 2015.
\end{abstract}

Keywords: trifloxystrobin; hatchability; biomarker; early life stages; medaka (Oryzias latipes)

Correspondence to: W. Li; e-mail: weili@rcees.ac.cn

Contract grant sponsor: National Natural Science Foundation of China. Contract grant numbers: 21007086 and 21277163. China.

Contract grant sponsor: The National Basic Research Program of

Contract grant number: 2012AA06A302.

*These authors contributed equally to this work.

Published online 23 December 2013 in Wiley Online Library (wileyonlinelibrary.com). DOI: 10.1002/tox.21942

\section{INTRODUCTION}

In recent years, several reports have detailed the release of fungicides applied on agriculture into aquatic ecosystems (Wightwick et al., 2012), and have been associated with a series of acute and chronic health effects of aquatic organisms (Li et al., 2010; McMahon et al., 2011). Trifloxystrobin \{methyl- $\alpha$-(methoxyimino)-2-[(\{1-[3-(trifluoromethyl)pheny1] ethylidene (amino)oxymethyl]benzeneacetate $\}$ is a systemic broad-spectrum foliar fungicide, which interferes with the respiration of plant-pathogenic fungi. It belongs to the strobilurin class of fungicides (Myung et al., 2013). Trifloxystrobin can be used to control fungi in greenhouse, nursery, 
orchard, vegetable, and paddy field crops. It exhibits activity against many fungal pathogens such as those in the ascomycete, basidiomycete, deuteromycete, and oomycete classes (Chen et al., 2008). Trifloxystrobin specifically affects anthracnose, downy mildew, powdery mildew, rice blast, rice sheath blight and false smut attacking vegetable, fruit and grain crops (Chen et al., 2008).

The use of trifloxystrobin has a potential risk to human and aquatic organisms through spray drift, direct overspray, atmospheric transport, field runoff, and animal movement. Previous studies have indicated that the use of trifloxystrobin lead to the presence of pesticide residues in fruits and processed products (Oliva et al., 2007; Jyot et al., 2010; Zhu et al., 2013). The half-life of trifloxystrobin on grape leaves was observed to be 2.92 and 3.48 days after a single and double application, respectively (Jyot et al., 2010). Moreover, as one of most frequently detected fungicides, the maximum measurable concentration of trifloxystrobin has been reported as $0.73 \mu \mathrm{g} / \mathrm{L}$ in surface water (Wightwick et al., 2012). Trifloxystrobin is considered to be less toxic to birds, mammals, bees, and other beneficial insects and earthworms, whereas a reduction in prey behavior was observed in eel and tadpole predator-prey systems exposed to sublethal trifloxystrobin concentrations (Junges et al., 2012). Trifloxystrobin has been classified as highly toxic to aquatic organisms, although a reduction in the toxicity of fungicide formulations by sediment is likely (Morrison et al., 2013). In addition, it has been reported that $\sim 40 \%$ of Bufo cognatus tadpoles died after exposure to trifloxystrobin formulation at environmentally relevant concentrations (Belden et al., 2010).

There is increasing concern regarding disorders in normal endocrine system function in wild fish caused by pesticides, including disruption in plasma hormone levels, retarded gonad growth and sexual maturation, and effects on reproduction (Baldwin et al., 2009; Lal et al., 2013). Several fungicides have effects consistent with endocrine disrupting chemicals. However, endocrine endpoints are seldom assessed among the sublethal effects of endocrine-active chemicals in fungicide studies. Previous studies have demonstrated that several genes are sensitive molecular biomarkers for endocrine system function in fish that were exposed to environmental contaminants. For sex hormone pathway evaluation, cytochrome P450c17 (CYP17) is the steroidogenic enzyme involved in testosterone production, and cytochrome P450c19 (CYP19) catalyzes the conversion of androgens to estrogens (Uno et al., 2012). Estrogens induce vitellogenin (VTG) production in the liver of fish through binding to estrogen receptors to exert its full biological effects (Nelson and Habibi, 2010). In addition, iodothyronine deiodinases (DIOs) are important regulators of thyroid hormone (TH) activity in teleosts (Orozco and Valverde, 2005). The biological activity of THs is mediated at the level of gene expression by $\mathrm{TH}$ receptor (TR) binding in fish (Marchand et al., 2001). Furthermore, aryl hydrocarbon receptor (AHR) binds to polyaromatic compounds and regulates the expression of CYP1A, a cytochrome P450 that mediates the toxic effects of such compounds (Hanno et al., 2010). These biomarkers present potential tools for the screening of endocrine disrupting effects in fish.

Early life stages of fish are important in the evaluation of the effects of potential toxicity in the aquatic environment because they are high sensitive to environmental chemicals at these stages. In this study, fertilized eggs were exposed to trifloxystrobin for 28 days. We detected the hatching and survival of embryos, and changes of er, vtg, cyp17, cyp19a, TRalpha (tr $\alpha$ ), DIO type II (dio2), ahr, and cypla genes mRNA levels of larval medaka. Our study aimed to investigate the effects of trifloxystrobin on development in the early life stages of medaka and to discuss the possible molecular mechanisms underlying the toxic response and endocrine disrupting effects.

\section{MATERIALS AND METHODS}

\section{Chemicals}

Trifloxystrobin was purchased from Sigma-Aldrich Chemical (USA). Stock solution of trifloxystrobin was prepared by dilution in HPLC-grade acetone. Working solutions were freshly made by diluting the stock solutions with dechlorinated tap water. The final vehicle of acetone in the test solution was $<0.001 \%$. All other chemicals were analytical or HPLC grade (Sigma Chemical, USA, or Beijing Chemical Reagents Company, China).

\section{Culture Conditions and Experimental Design}

The Japanese medaka (d-rR) stock used in this study originated from the State Key Laboratory of Environmental Aquatic Chemistry, Research Center for Eco-Environmental Sciences, Chinese Academy of Sciences, China. The brood stock of medaka was raised in a flow-through system with dechlorinated tap water $(\mathrm{pH}=7.2-7.6$; hardness $=44.0-$ $\left.61.0 \mathrm{mg} \mathrm{CaCO}_{3} / \mathrm{L}\right)$ at a constant temperature $\left(25 \pm 1^{\circ} \mathrm{C}\right)$ with a photoperiod of 16:8 h (light:dark). Fish were fed with a commercial pellet food (Tetra, Germany) at a rate of $0.1 \%$ body weight per day, as well as newly hatched brine shrimp (Artemia) nauplii (Haifa, China) twice daily. Waste and residue were removed daily and the test equipment and chambers were cleaned once per week.

Embryos aged at $<4 \mathrm{~h}$ postfertilization were used in the exposure experiments. Eggs spawned from stock females were carefully collected within a few hours after fertilization. Filaments attaching adjacent eggs were removed to separate individual eggs from the rest of the clusters. Eggs were then disinfected by placing them in a $0.9 \%$ solution of hydrogen peroxide for $10 \mathrm{~min}$ and checked for fertilization using a dissecting microscope. Fertilization was identified by the migration of oil globules to the vegetal pole. For each 
TABLE I. Primers used for PCR and the quantification of the mRNA expression by real-time PCR

\begin{tabular}{|c|c|c|c|}
\hline Gene & Sequence $\left(5^{\prime} \rightarrow 3^{\prime}\right)$ & Product size (bp) & Genbank accession no. \\
\hline \multirow[t]{2}{*}{ rpl7 } & F: CGCCAGATCTTCAACGGTGTAT & 72 & NM001104870 \\
\hline & R: AGGCTCAGCAATCCTCAGCAT & & \\
\hline \multirow[t]{2}{*}{ Er } & F:GAGAGCACTGAAGACACGCT & 84 & D28954 \\
\hline & R: AGGCACAGAGAACAAAGTCCT & & \\
\hline \multirow[t]{2}{*}{ Vtg } & F: CAGGTTGCCAGCTTCACATAC & 128 & NM001104677 \\
\hline & R: CTCAGTCTGTCCAGCTTTGG & & \\
\hline \multirow[t]{2}{*}{ Cyp17 } & F:GACACCAGCCTCGGAGATTTC & 70 & NM001105094 \\
\hline & R:GGTGCAGAGACCACAGGTTGA & & \\
\hline \multirow[t]{2}{*}{ Cyp19a } & F: ACTGTAGGACTCCCATCCG & 94 & NM001278879 \\
\hline & R:TCTTCTCACTGTGACTCCAGA & & \\
\hline \multirow{2}{*}{$\operatorname{Tr} \alpha$} & F: ACCCGTCCTACTCCTGTAAGT & 120 & NM001104705 \\
\hline & R: ACACCAAGTCCATCGCCAT & & \\
\hline \multirow[t]{2}{*}{ Dio2 } & F:CATGGACAACAATGCGAACG & 109 & NM001136521 \\
\hline & R:GTTGTAGAAAAATGCCCCCTTG & & \\
\hline \multirow[t]{2}{*}{$A h r$} & F: GACGGCTGAAGTATCTCCAG & 160 & XM004082032 \\
\hline & R: TCCAGCTTGTGTTTGGTCTT & & \\
\hline \multirow[t]{2}{*}{ Cypla } & F: TGGTTTTTGGTCTGGGAAA & 86 & NM001105087 \\
\hline & R: TGAATCATGATTGCCAAAAA & & \\
\hline
\end{tabular}

exposure level, 90 embryos were randomly separated into three equal groups. Embryos were exposed to nominal trifloxystrobin concentrations of $0,0.1,1,10$, and $100 \mu \mathrm{g} / \mathrm{L}$ in dilution water containing $1 \%$ methylene blue until hatching. The embryos in each group were placed in a glass dish containing $100 \mathrm{~mL}$ of each test solution and incubated on a 16:8 h (light:dark) photoperiod cycle at $25 \pm 1{ }^{\circ} \mathrm{C}$. Every 24 h, $80 \%$ of the test solution was renewed. Embryos were observed twice daily at which point dead embryos (identified by the incorporation of methylene blue) were removed.

The total experimental period was 28 days. After hatching, larvae were transferred to glass beakers containing 500 $\mathrm{mL}$ of control or test solution, and triplicate beakers were prepared for each solution. The exposure conditions (including water temperature and photoperiod) and trifloxystrobin concentrations for larvae were the same as those used for the embryos. The test solutions were $80 \%$ renewed every $24 \mathrm{~h}$. After 3 days post hatching, larvae were fed newly hatched brine shrimp (Artemia) nauplii twice daily. Waste and residue were removed daily. The larvae were observed twice daily and dead larvae, characterized by no heart activity, were removed. The larvae were also observed for morphological effects of the treatment. At the end of the exposure, the remaining fish were measured for total length. At least 6 larvae in each beakers were collected and mixed together as one sample, resulting in a minimum of three pooled samples analyzed per treatment. Larvae were sacrificed in an ice bath and stored at $-80^{\circ} \mathrm{C}$ until RNA extraction.

\section{Water Concentration of Trifloxystrobin}

Water samples were collected every week and trifloxystrobin concentrations were analyzed. The samples were extracted with ethyl acetate in an ultrasonic water bath and analyzed by HPLC-MS-MS (Agilent 1260-G6460B QQQ manufactured by Agilent Technologies). The chromatographic separation was performed using a $4.6 \times 100 \mathrm{~mm} \times 3.5 \mu \mathrm{m}$ Agilent C18 column (Agilent Technologies, USA). The mobile phase was a 10:90 (v/v) mixture of $10 \mathrm{mM}$ aqueous ammonium formate and acetonitrile. The flow rate was 300 $\mu \mathrm{L} /$ min with an injection volume of $10 \mu \mathrm{L}$. ESI was performed in positive-ion mode with the parameters of $15.0 \mathrm{psi}$ nebulizing gas $\left(\mathrm{N}_{2}\right)$ pressure, $3.5 \mathrm{kv}$ capillary voltage, fragment $80 \mathrm{v}$ voltage, and collision energy of $7 \mathrm{v}$. Trifloxystrobin was identified and quantified in the selected reaction monitored at m/z 409/186 and 409/145. The instrument limits of detection and quantitation (LOQ) were 0.008 and $0.028 \mu \mathrm{g} / \mathrm{L}$, respectively, calculated as 3 and 10 times the signal-to-noise ratio $(\mathrm{S} / \mathrm{N})$. The analyzed concentrations (mean $\pm \mathrm{SD}$; and \% analyzed/nominal) of trifloxystrobin in the test solutions during the exposure period were $0.08 \pm 0.02(80 \%), 0.86 \pm 0.14(86 \%), 8.52 \pm 2.14(85 \%)$, and $88.37 \pm 5.35(88 \%) \mu \mathrm{g} / \mathrm{L}$. Nominal trifloxystrobin values are used in the following text.

\section{Real-Time PCR}

RNA-isolation, reverse-transcription, and real-time PCR were performed following previously described methods $(\mathrm{Li}$ et al., 2009a). The forward and reverse primers used and PCR products are listed in Table I. All of the samples were analyzed in triplicate and the mean value of these triplicate measurements was used for the calculations of mRNA expression in larvae. The results were analyzed according to the delta-delta $\mathrm{Ct}$ method (Livak and Schmittgen, 2001). The mRNA expression of er, vtg, cyp 17, cyp 19a, tro, dio2, 
TABLE II. Hatchability and time to hatching of fertilized eggs, and mortality and body length of larvae after exposure to trifloxystrobin

\begin{tabular}{|c|c|c|c|c|}
\hline \multirow[b]{2}{*}{ Concn. $(\mu \mathrm{g} / \mathrm{L})$} & \multicolumn{2}{|c|}{ Fertilized eggs } & \multicolumn{2}{|c|}{ Larvae } \\
\hline & Hatchability (\%) & Time to hatching (days) & Mortality (\%) & Body length (mm) \\
\hline Control & $78.3 \pm 12.6$ & $9.6 \pm 0.6$ & $24.5 \pm 3.5$ & $6.2 \pm 1.0$ \\
\hline 0.1 & $85.0 \pm 7.1$ & $9.5 \pm 0.2$ & $33.3 \pm 3.0^{\mathrm{a}}$ & $5.7 \pm 0.8$ \\
\hline 1 & $68.3 \pm 4.3$ & $9.6 \pm 0.6$ & $36.0 \pm 2.4^{\mathrm{a}}$ & $6.6 \pm 0.6$ \\
\hline 10 & $73.3 \pm 13.9$ & $9.3 \pm 0.4$ & $34.6 \pm 4.6^{\mathrm{a}}$ & $6.2 \pm 0.5$ \\
\hline 100 & $62.4 \pm 25.7^{\mathrm{a}}$ & $12.3 \pm 1.4^{\mathrm{a}}$ & $29.3 \pm 2.7$ & $5.6 \pm 0.7$ \\
\hline
\end{tabular}

Data expressed as mean \pm SD of each treatment.

${ }^{\text {a }}$ Statistically significant difference from the control $(p<0.05)$.

$a h r$, and cypla mRNA was normalized to $r p l 7$ mRNA expression. Dissociation curve analysis was performed for each gene to check the amplification of untargeted fragments. Only one peak was observed for each amplification, indicative of amplification of the target gene only. Gene expression data are presented as the fold change relative to control fish within the same treatment period.

\section{Statistics}

All statistical analyses were performed using SPSS (version 16.0; USA). All quantitative data are expressed as the mean \pm SEM. Statistical analysis of the data was performed using analysis of variance followed by Bonferroni's multiple comparison test after a comparison of the homogeneity of variance (Bartlett's test). A $p$ value of $<0.05$ was considered significant, and $p<0.01$ was considered highly significant.

\section{RESULTS}

\section{Embryonic Developmental Toxicity}

Eggs aged $<4 \mathrm{~h}$ post-fertilization were continuously exposed to trifloxystrobin through the embryonic stages, hatching and into the larval stage. Hatchability and time to hatching were measured after exposure to trifloxystrobin (Table II). Hatchability of fertilized eggs exposed to trifloxystrobin at $100 \mu \mathrm{g} / \mathrm{L}$ was significantly decreased relative to the control eggs $(p<0.05)$. Time to hatching was also significantly delayed in the $100 \mu \mathrm{g} / \mathrm{L}$ treatment group compared to the control group $(p<0.05)$. Pericardial edema and hemorrhage were observed along with retarded development of embryos after 9 days exposure in the $100 \mu \mathrm{g} / \mathrm{L}$ treatment group (Fig. 1).

\section{Larvae Toxicity}

Larval mortality was measured at the end of the trifloxystrobin exposure period (Table II). Larval mortality was significantly increased in the $0.1,1$, and $10 \mu \mathrm{g} / \mathrm{L}$ treatment groups $(p<0.05)$. Medaka larvae death was primarily observed within 4-7 days after hatching, and the common causes of larval death were scoliosis and swim-up failure. At the end of the trifloxystrobin exposure period, there were no significant differences in body length between the treatment groups and the controls.

\section{Quantitation of mRNA in Larvae}

The mRNA levels of er, vtg, cyp17, and cyp19a in the larvae were determined after exposure to trifloxystrobin (Fig. 2). The mRNA levels of er were significantly upregulated in the treatment groups above $1 \mu \mathrm{g} / \mathrm{L}(p<0.05)$. The expression of $v t g$ mRNA levels were significantly up-regulated only in the 0.1 and $1 \mu \mathrm{g} / \mathrm{L}$ treatment groups. At the end of the exposure, the up-regulation of cyp17 and cyp $19 a$ mRNA levels were observed in the larvae of the $0.1,1$, and $10 \mu \mathrm{g} / \mathrm{L}$ treatment groups, whereas there was no significant difference between controls and the $100 \mu \mathrm{g} / \mathrm{L}$ treatment group.

The expression of tra, dio2, ahr, and cypla mRNA levels in the larvae were determined after trifloxystrobin exposure (Fig. 3). There was no significant difference in the expression of $t r \alpha$, dio2, and ahr mRNA levels of treated larvae compared with the controls at the end of the exposure. The mRNA levels of the cypla gene were significantly up-regulated at all the treatment levels $(p<0.01)$. A strong dose-response relationship were observed between doses of trifloxystrobin and up-regulation of cypla mRNA levels.

\section{DISCUSSION}

This study is the first to use a small fish model, Japanese medaka, to assess the effects of trifloxystrobin on hatchability and time to hatching of embryos, as well as changes in the expression of genes involved in the sex hormone pathway, TH pathway, and aryl hydrocarbon receptor pathway in larvae under laboratory conditions. Trifloxystrobin exposure resulted in embryo lesions, hatchability decrease, and changes in the expression of sex hormone and aryl hydrocarbon receptor pathway-related genes. 

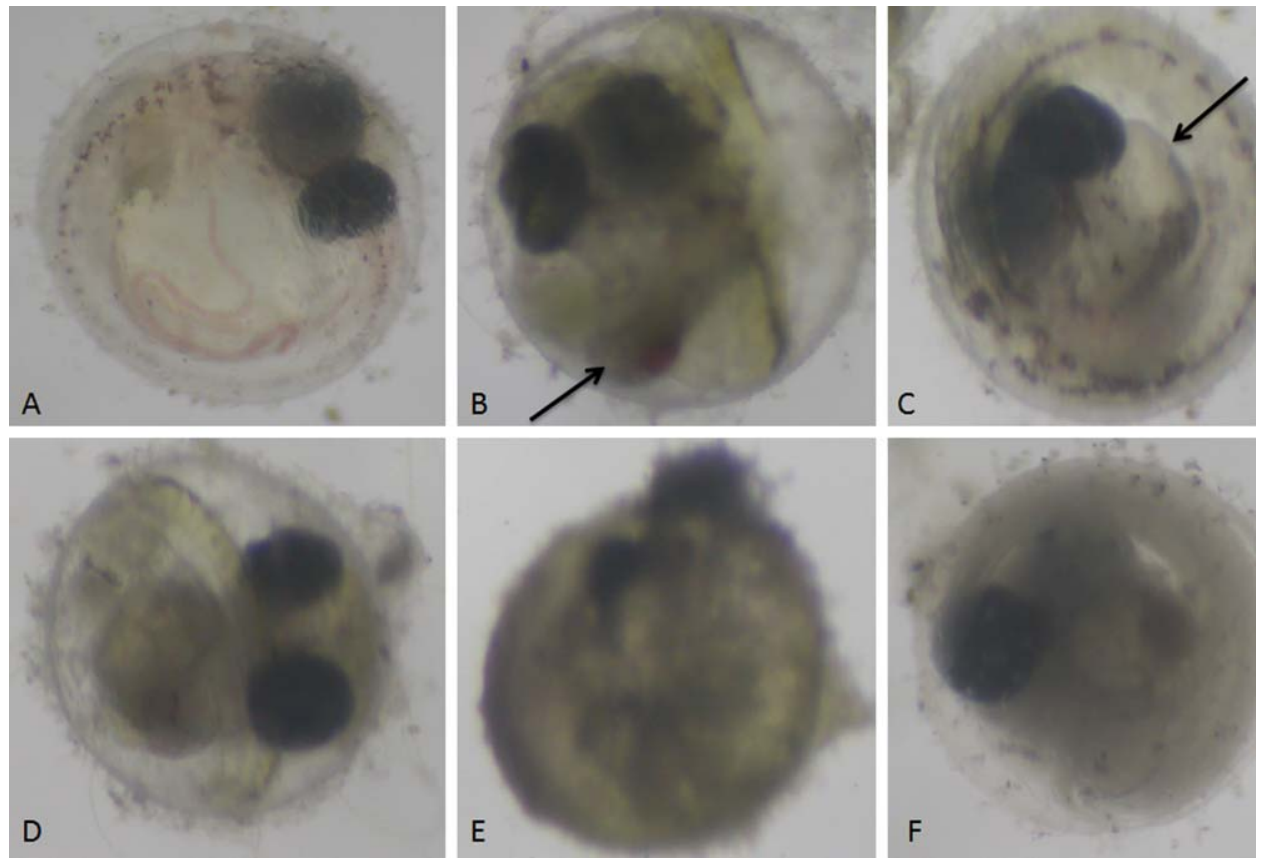

Fig. 1. Gross morphology of trifloxystrobin-treated embryos, (A) normal embryo; (B) lesion embryo from $100 \mu \mathrm{g} / \mathrm{L}$ treatment group, arrow shows hemorrhage; (C) lesion embryo from $100 \mu \mathrm{g} / \mathrm{L}$ treatment group, arrow shows pericardial edema; (D) retarded development of embryo from $100 \mu \mathrm{g} / \mathrm{L}$ treatment group after 9 days exposure; (E) embryonic death from $100 \mu \mathrm{g} / \mathrm{L}$ treatment group after 12 days exposure; (F) embryonic death from $100 \mu \mathrm{g} / \mathrm{L}$ treatment group after 12 days exposure. [Color figure can be viewed in the online issue, which is available at wileyonlinelibrary.com.]
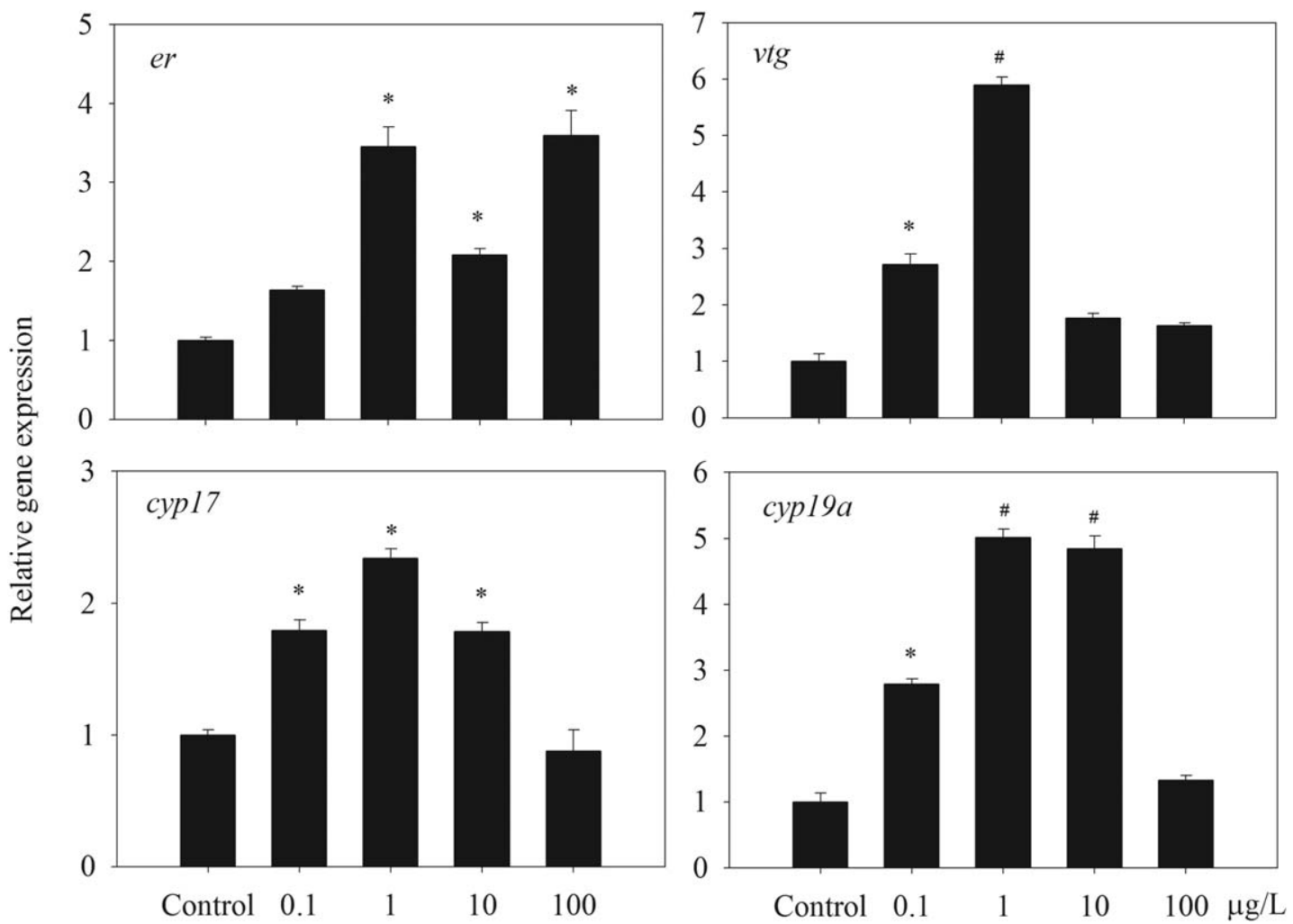

Fig. 2. Relative expression levels of er, vtg, cyp17, and cyp19a in larval medaka after 28 days of exposure to trifloxystrobin. The results were evaluated as the relative ratio of the expression level of each mRNA to that of rp/7. Data expressed as mean \pm SEM of each treatment $(n=3) .{ }^{*} p<0.05$, \#p $<0.01$, relative to control. 


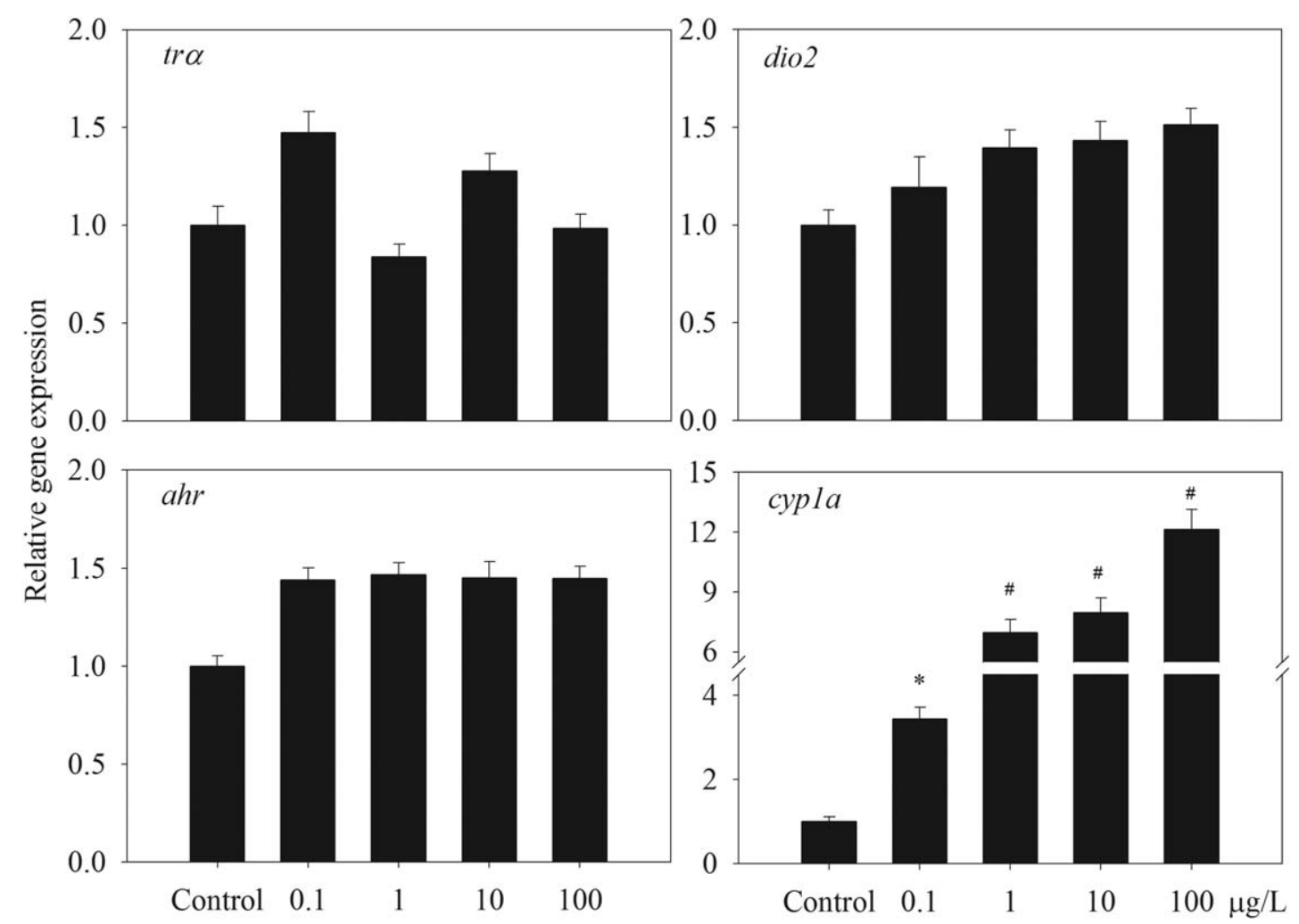

Fig. 3. Relative expression levels of tr $\alpha$, dio2, ahr, and cyp1a in larval medaka after 28 days of exposure to trifloxystrobin. The results were evaluated as the relative ratio of the expression level of each mRNA to that of rp/7. Data expressed as meanSEM of each treatment $(n=3) .{ }^{*} p<0.05$, \#p $<0.01$, relative to control.

The early life stages of fish are considered relatively sensitive to toxicants and endocrine disrupting chemicals (EDCs). Hatchability is an important indicator that is directly related to the quality of the larvae, ultimately affecting the survival of a species (Zha and Wang, 2005). Hatchability is sensitive to changes in the environment and can be a sensitive index for the evaluation of the toxicity of various substances. In this study, hatchability was significantly decreased in the $100 \mu \mathrm{g} / \mathrm{L}$ treatment group relative to the controls. Time to hatching was also significantly delayed in the $100 \mu \mathrm{g} / \mathrm{L}$ treatment group. Previous studies have shown that a reduction in hatching success of medaka was observed after exposure to the fungicide pentachloronitrobenzene (Metcalfe et al., 2008). Three xenoestrogens, nonylphenol, $17 \beta$-estradiol, and bisphenol A, led to retarded embryonic development and lengthened the time to hatching in transgenic medaka embryos (Lee et al., 2012). Moreover, swim-up failure is considered to be the consequence of chronic intoxication for larval fish (Zha and Wang, 2005). Our studies showed that the common causes of increased larval mortality were scoliosis and swim-up failure within 4-7 days post hatching (mouth-open period). However, body length does not appear to be a sensitive indicator for exposure to trifloxystrobin in early life stages. The decrease in hatch- ability at the treatment level of $100 \mu \mathrm{g} / \mathrm{L}$, and the increase in larval mortality at low concentrations indicated that trifloxystrobin may cause cumulative toxicity to medaka embryos. Taken together, these results indicated that trifloxystrobin could impact the development of early life stages of fish.

Sex hormones play an important role in sex differentiation, sexual development, and normal reproduction of fish (Rougeot et al., 2007; Lubzens et al., 2010). Molecular biomarkers of the sex hormone pathway are generally used to assess endocrine disruption in teleosts. Previous studies have demonstrated that the expression level of $e r$ mRNA in fish was affected by xenoestrogens (Min et al., 2003). Abnormal VTG induction is traditionally used as a biomarker of EDCs in fish. In addition, as the key steroidogenic enzymes to sex hormone biosynthesis, CYP17 and CYP19 are the subject of mechanistic studies that focus on EDC interference with sex hormone homeostasis and function (Sanderson, 2006). Our studies found that the mRNA levels of the er gene were significantly up-regulated in treatment groups above $1 \mu \mathrm{g} / \mathrm{L}$. The expression of $v t g$, cyp17, and cyp19a mRNA levels were significantly up-regulated at lower treatment concentrations. Previous research has confirmed that the expression of $e r$ and cyp19 mRNA levels were up-regulated in liver of female medaka after exposure to typical EDCs 
$17 \beta$-estradiol, nonylphenol, and bisphenol A (Min et al., 2003). A similar study performed in transgenic medaka embryos revealed that these EDCs can up-regulate era mRNA level (Lee et al., 2012). During early development of zebrafish, 17 $\alpha$-ethinylestradiol exposure could significantly increase the VTG concentration (Andersen et al., 2003). The expression of $v t g$ and $e r$ mRNA levels were significantly induced in larvae after 7 days of exposure to $17 \beta$-estradiol and nonylphenol, respectively (Jin et al., 2009). In this study, the changes in expression of sex hormone pathway genes indicated that trifloxystrobin could disrupt sex hormone function in fish. The bell-shaped concentration-response profile suggests that toxic effect may occur in the $100 \mu \mathrm{g} / \mathrm{L}$ treatment group due to a stress concentration.

Thyroid hormone is essential for developmental and physiological functions in fish. TH receptor and deiodinase gene expression was used as sensitive molecular biomarkers of thyroid disruption in fish (Li et al., 2009b). Our data demonstrated that there was no significant difference in the expression of $\operatorname{tr} \alpha$ and dio 2 mRNA levels in trifloxystrobin-treated larvae in comparison to the controls at the end of the exposure. Previous studies have shown that the $d i o 2, \operatorname{tr} \alpha$, and $\operatorname{tr} \beta$ mRNAs levels were increased in juvenile female fish and in the brains of adult female medaka after exposure to metolachlor (Jin et al., 2011). To our knowledge, no data are available for a comparison of the changes of tr $\alpha$ and dio 2 mRNA levels in larval medaka. The data suggest that exposure to trifloxystrobin did not affect the expression of the TH receptor and deiodinase genes in medaka larvae.

The AHR is a ligand-activated transcription factor involved in the regulation of xenobiotic metabolizing enzymes (Zhou et al., 2010). It may control levels of cytochrome P450s that are responsible for the metabolism of xenobiotics that cause abnormal phenotypes in fish (Kawamura and Yamashita, 2002). The AHR can mediate E2induced expression of the VTG gene (Bemanian et al., 2004). This study showed that a strong dose-response relationship was observed between doses of trifloxystrobin. Additionally, up-regulation of cypla mRNA levels were dose dependent, but no significant differences in the expression of $a h r$ mRNA levels of larvae were observed. Previous research has indicated that the transcription of ahr and cypla was significantly induced in the early life stages of medaka embryos after exposure to dioxin isomers (Hanno et al., 2010). The changes of cypla gene expression were tissuespecific after exposure to organic contaminants in marine medaka (Woo et al., 2009). Further studies are needed to investigate the distribution of trifloxystrobin in different tissues and corresponding histological lesions and changes of gene transcription in adult fish after exposure. This data suggest that trifloxystrobin may induce xenobiotic metabolism. The changes in cypla expression can be used as a sensitive biomarker to assess trifloxystrobin contamination in early life stages of fish.

\section{CONCLUSION}

In this study, medaka embryos were employed to assess the toxic effects of trifloxystrobin on the early life stages of fish. The mRNA levels of functional genes involved in the sex hormone pathway, TH pathway, and aryl hydrocarbon receptor pathway were investigated to screen for molecular biomarkers and evaluate the endocrine disrupting effects in larvae. Exposure to trifloxystrobin can result in embryonic lesions, decreased hatchability, and increased larval mortality in embryonic and larval medaka. These results indicate that trifloxystrobin can impact the development in early life stages of fish. The changes in expression of sex hormone and aryl hydrocarbon receptor pathway genes demonstrated that trifloxystrobin can disrupt sex hormone function and induce xenobiotic metabolism in larval fish. The cypla gene prenents a potential sensitive biomarker for the assessment of trifloxystrobin contamination in early life stages of fish. Further studies are needed to unravel the distribution of trifloxystrobin in different tissues, histological lesions, and regulation of gene transcription in adult fish exposure to the fungicide.

\section{REFERENCES}

Andersen L, Holbech H, Gessbo A, Norrgren L, Petersen GI. 2003. Effects of exposure to 17alpha-ethinylestradiol during early development on sexual differentiation and induction of vitellogenin in zebrafish (Danio rerio). Comp Biochem Physiol C Toxicol Pharmacol 134:365-374.

Baldwin DH, Spromberg JA, Collier TK, Scholz NL. 2009. A fish of many scales: extrapolating sublethal pesticide exposures to the productivity of wild salmon populations. Ecol Appl 19: 2004-2015.

Belden J, McMurry S, Smith L, Reilley P. 2010. Acute toxicity of fungicide formulations to amphibians at environmentally relevant concentrations. Environ Toxicol Chem 29:2477-2480.

Bemanian V, Male R, Goksoyr A. 2004. The aryl hydrocarbon receptor-mediated disruption of vitellogenin synthesis in the fish liver: Cross-talk between AHR- and ERalpha-signalling pathways. Comp Hepatol 3:2.

Chen J, Loo B, Ray C. 2008. Determination of trifloxystrobin and its metabolites in Hawaii soils by ASE-LC-MS/MS. J Agric Food Chem 56:1829-1837.

Hanno K, Oda S, Mitani H. 2010. Effects of dioxin isomers on induction of AhRs and CYP1A1 in early developmental stage embryos of medaka (Oryzias latipes). Chemosphere 78: 830-839.

Jin Y, Chen R, Sun L, Qian H, Liu W, Fu Z. 2009. Induction of estrogen-responsive gene transcription in the embryo, larval, juvenile and adult life stages of zebrafish as biomarkers of short-term exposure to endocrine disrupting chemicals. Comp Biochem Physiol C Toxicol Pharmacol 150:414-420.

Jin Y, Chen R, Wang L, Liu J, Yang Y, Zhou C, Liu W, Fu Z. 2011. Effects of metolachlor on transcription of thyroid system- 
related genes in juvenile and adult Japanese medaka (Oryzias latipes). Gen Comp Endocrinol 170:487-493.

Junges CM, Peltzer PM, Lajmanovich RC, Attademo AM, Cabagna Zenklusen MC, Basso A. 2012. Toxicity of the fungicide trifloxystrobin on tadpoles and its effect on fish-tadpole interaction. Chemosphere 87:1348-1354.

Jyot G, Arora PK, Sahoo SK, Singh B, Battu RS. 2010. Persistence of trifloxystrobin and tebuconazole on grape leaves, grape berries and soil. Bull Environ Contam Toxicol 84:305-310.

Kawamura T, Yamashita I. 2002. Aryl hydrocarbon receptor is required for prevention of blood clotting and for the development of vasculature and bone in the embryos of medaka fish, Oryzias latipes. Zool Sci 19:309-319.

Lal B, Sarang MK, Kumar P. 2013. Malathion exposure induces the endocrine disruption and growth retardation in the catfish, Clarias batrachus (Linn.). Gen Comp Endocrinol 181:139-145.

Lee W, Kang CW, Su CK, Okubo K, Nagahama Y. 2012. Screening estrogenic activity of environmental contaminants and water samples using a transgenic medaka embryo bioassay. Chemosphere 88:945-952.

Li W, Zha J, Li Z, Yang L, Wang Z. 2009a. Effects of exposure to acetochlor on the expression of thyroid hormone related genes in larval and adult rare minnow (Gobiocypris rarus). Aquatic Toxicol 94:87-93.

Li W, Zha J, Spear PA, Li Z, Yang L, Wang Z. 2009b. Changes of thyroid hormone levels and related gene expression in Chinese rare minnow (Gobiocypris rarus) during 3-amino-1,2,4-triazole exposure and recovery. Aquatic Toxicol 92:50-57.

Li ZH, Zlabek V, Grabic R, Li P, Machova J, Velisek J, Randak T. 2010. Effects of exposure to sublethal propiconazole on the antioxidant defense system and $\mathrm{Na}+-\mathrm{K}+$-ATPase activity in brain of rainbow trout, Oncorhynchus mykiss. Aquatic Toxicol 98:297-303.

Livak KJ, Schmittgen TD. 2001. Analysis of relative gene expression data using real-time quantitative PCR and the 2(-Delta Delta C(T)) Method. Methods 25:402-408.

Lubzens E, Young G, Bobe J, Cerda J. 2010. Oogenesis in teleosts: how eggs are formed. Gen Comp Endocrinol 165:367-389.

Marchand O, Safi R, Escriva H, Van Rompaey E, Prunet P, Laudet V. 2001. Molecular cloning and characterization of thyroid hormone receptors in teleost fish. J Mol Endocrinol 26:51-65.

McMahon TA, Halstead NT, Johnson S, Raffel TR, Romansic JM, Crumrine PW, Boughton RK, Martin LB, Rohr JR. 2011. The fungicide chlorothalonil is nonlinearly associated with corticosterone levels, immunity, and mortality in amphibians. Environ Health Perspect 119:1098-1103.

Metcalfe TL, Dillon PJ, Metcalfe CD. 2008. Effects of formulations of the fungicide, pentachloronitrobenzene on early life stage development of the Japanese medaka (Oryzias latipes). Chemosphere 71:1957-1962.
Min J, Lee SK, Gu MB. 2003. Effects of endocrine disrupting chemicals on distinct expression patterns of estrogen receptor, cytochrome P450 aromatase and p53 genes in oryzias latipes liver. J Biochem Mol Toxicol 17:272-277.

Morrison SA, McMurry ST, Smith LM, Belden JB. 2013. Acute toxicity of pyraclostrobin and trifloxystrobin to Hyalella azteca. Environ Toxicol Chem 32:1516-1525.

Myung K, Williams DA, Xiong Q, Thornburgh S. 2013. Metabolism of strobilurins by wheat cell suspension cultures. J Agric Food Chem 61:47-52.

Nelson ER, Habibi HR. 2010. Functional significance of nuclear estrogen receptor subtypes in the liver of goldfish. Endocrinology 151:1668-1676.

Oliva J, Paya P, Camara MA, Barba A. 2007. Removal of famoxadone, fluquinconazole and trifloxystrobin residues in red wines: effects of clarification and filtration processes. J Environ Sci Health B 42:775-81.

Orozco A, Valverde RC. 2005. Thyroid hormone deiodination in fish. Thyroid 15:799-813.

Rougeot C, Krim A, Mandiki SN, Kestemont P, Melard C. 2007. Sex steroid dynamics during embryogenesis and sexual differentiation in Eurasian perch, Perca fluviatilis. Theriogenology 67:1046-1052.

Sanderson JT. 2006. The steroid hormone biosynthesis pathway as a target for endocrine-disrupting chemicals. Toxicol Sci 94: $3-21$.

Uno T, Ishizuka M, Itakura T. 2012. Cytochrome P450 (CYP) in fish. Environ Toxicol Pharmacol 34:1-13.

Wightwick AM, Bui AD, Zhang P, Rose G, Allinson M, Myers JH, Reichman SM, Menzies NW, Pettigrove V, Allinson G. 2012. Environmental fate of fungicides in surface waters of a horticultural-production catchment in southeastern Australia. Arch Environ Contam Toxicol 62:380-390.

Woo S, Yum S, Kim DW, Park HS. 2009. Transcripts level responses in a marine medaka (Oryzias javanicus) exposed to organophosphorus pesticide. Comp Biochem Physiol C Toxicol Pharmacol 149:427-432.

Zha J, Wang Z. 2005. Assessing technological feasibility for wastewater reclamation based on early life stage toxicity of Japanese medaka (Oryzias latipes). Agric Ecosystems Environ 107:187-198.

Zhou H, Qu Y, Wu H, Liao C, Zheng J, Diao X, Xue Q. 2010. Molecular phylogenies and evolutionary behavior of AhR (aryl hydrocarbon receptor) pathway genes in aquatic animals: implications for the toxicology mechanism of some persistent organic pollutants (POPs). Chemosphere 78:193-205.

Zhu J, Dai XJ, Fang JJ, Zhu HM. 2013. Simultaneous detection and degradation patterns of kresoxim-methyl and trifloxystrobin residues in citrus fruits by HPLC combined with QuEChERS. J Environ Sci Health B 48:470-476. 